\title{
The Myth of the All-Destructive War: Afterthoughts on German Suffering, 1618-1648*
}

\author{
David Lederer
}

\section{I: Do Germans Suffer?}

A provocative question, perhaps, but taken to the superlative, it immediately caricatures several major theoretical and methodological problems of modern German historiography. Absurd as it seems on the surface, there is more to this rhetorical flourish than first meets the eye, and its ideological roots run deeper than one might expect. A partisan earnestness characterizing current discussions on victimization during the Second World War has given rise to unease. One such discussion concentrates on the traumatizing effects of Allied bombing on the German civilian population. Discussions over the post-unification memorialization of this and other aspects of German wartime suffering (such as civilian losses at the front, civilian casualties during the torpedoing of the Wilhelm Gustloff, or expatriate Germans seeking reparations from countries in East Central Europe), have proved surprisingly contentious. ${ }^{1}$ Anxiety over the normalization of twenty-first century memories of past suffering in Germany threatens to reopen the old wounds of the 'historians' dispute' (Historikerstreit).

Far from a resuscitation attempt on the corpse of the Sonderweg, a sober evaluation of the current state of historiography on the Thirty Years War offers us an ironically reversed perspective on German suffering, thereby evidencing theoretical paradoxes in master narratives of modern German history. Beyond providing us with a compelling contrast, the present afterthoughts on suffering during the tragic three decades from 1618 to 1648 remind us of general obstacles to any historical representation of emotional suffering. ${ }^{2}$ They query whether a universal understanding of suffering is politically viable or even desirable, and whether the historical study of suffering in wartime is ultimately useful or simply a fashionable question mal posée.

\footnotetext{
* Support for this study was provided by a grant from the Wellcome Trust for the History of Medicine under the auspices of research on the history of despair conducted in conjunction with the Centre for the History of the Emotions, Queen Mary, University of London, and research on fear during the Thirty Years War conducted as a fellow at the Shelby-Cullom Davis Center, Princeton University, during the 2008 cycle on the history of fear.

${ }^{1}$ See the discussion in Central European History, 38 (2005), especially the fine overview of the debate instigated by J. Friedrich's Der Brand: Deutschland im Bombenkrieg, 1940-45 (Berlin, 2003) by M. Nolan, 'Germans as Victims during the Second World War: Air Wars, Memory Wars', pp. 7-40. Conference collections continue to take up the theme, among them: L. Cohen-Pfister and D. Wienröder-Skinner (eds), Victims and Perpetrators, 1933-1945: (Re)Presenting the Past in Post-Unification Culture (Berlin and New York, 2006); B. Niven and C. Paver (eds), Memorialization in Germany since 1945 (Basingstoke, 2010); G. Margalit (ed.), Guilt, Suffering and Memory: Germany Remembers its Dead of World War II (Bloomington, 2010).

${ }^{2}$ As an emotion, suffering is both biologically universal (nature) and culturally constructed (nurture), a historical problem cogently analysed by W. Reddy, The Navigation of Feeling: A Framework for the History of Emotions (Cambridge, 2001).
} 
Contradictory perceptions of German suffering during the two wars - the Second World War and the Thirty Years War-poignantly illustrate the basic underlying paradox. In the Second World War, German suffering is viewed against the backdrop of an evil dictatorship held legally responsible for the war and its consequences. In this scenario, German suffering is mitigated by the Nazi regime, democratically elected by the German people. As willing supporters, their implied culpability lessens suffering resulting from a war justly prosecuted against them. In the Thirty Years War, however, no such legalistic contention can be presumed. Politically, the imperial estates did not express the popular will. In stark contrast to the Second World War, political memories of the Thirty Years War have faded, leaving us little more than a legacy of suffering. Today, secular historians usually define it as a pointless struggle brought on by irrational religious intolerance that quickly devolved into a senseless orgy of violence and mayhem. Modern historians generally view the final outcome of the Thirty Years War as politically indecisive at best and, at worst, a European tragedy. As Ronald Asch puts it, the war was 'one of the longest and, in its later stages, most indecisive military contests in the history of early modern Europe'. Peace followed in 1648 not as the consequence of a total defeat of one or the other powers, but because the principal belligerents, 'were too exhausted to continue fighting, at least on the same scale as during the past decades' ${ }^{3}$ Accordingly, the principal belligerents simply agreed to quit without adjudicating blame in Münster and Osnabrück. Powers such as the Papacy, which refused to sign the Peace of Westphalia since it recognized the legal rights of Protestants, were effectively sidelined. Taken to its logical conclusion, suffering becomes the central meaning of the Thirty Years War.

By the eighteenth century, the conflict from 1618 to 1648 had already entered encyclopedic memory as the great 'German War', but the article in Zedler's Universallexicon concerned itself solely with a narrative of political and military events from a Protestant perspective, passing over the issue of human suffering in silence. ${ }^{4}$ Contrarily, early modernists now cite a twentieth-century survey that calls attention to the enduring scars etched upon the German psyche by the Thirty Years War to substantiate Germany's long-term collective memory. In 1962, an official questionnaire distributed among the rural population of Hesse listed seven great catastrophes in German history and requested participants to rank them. In their responses, the Thirty Years War still occupied pride of place, followed by the German defeat in the Second World War, the Third Reich, the Black Death, the defeat in the First World War, the Napoleonic Wars and the Seven Years War, in cardinal order. Comparisons between sufferings during the Kosovo conflict and the Thirty Years War were a recurrent theme in the German media as late as the 1990s. ${ }^{5}$ In the collective German consciousness of the twentieth century, the Thirty Years War provided a rare and politically correct moment-in-time for self-referential lamentations of national grief otherwise relativized

${ }^{3}$ R. Asch, The Thirty Years War: The Holy Roman Empire and Europe, 1618-1648 (Basingstoke, 1997), p. 150.

${ }^{4}$ J.H. Zedler, Grosses vollständiges Universallexicon aller Wissenschaften und Künste, vol. 7, 1453f. (search for 'Dreyßig-jähriger oder Teutscher Krieg' at www.zedler-lexikon.de/suchen/suchergebnisse.html?suchmodus= standard, accessed 1 Sept. 2010).

${ }^{5} \mathrm{H}$. Medick and B. von Krusenstjern, 'Einleitung: Die Nähe und Ferne des Dreißigjährigen Krieges', in Krusenstjern and Medick (eds), Zwischen Alltag und Katastrophe: Der Dreißigjährige Krieg aus der Nähe (Göttingen, 2001), pp. 34-36. The Hessian survey is cited most recently in P.H. Wilson's monumental study, The Thirty Years War: Europe's Tragedy (Cambridge, Mass., 2009), p. 6. 
by the injustice of the Holocaust. ${ }^{6}$ Zedler's Universallexicon could not possibly have envisioned this.

For seventeenth-century Europeans, religious tensions instilled suffering with strong sectarian connotations of Christian justification with decidedly moralist overtones. Baroque literature generally evinced a macabre familiarity with death and suffering, recognizing many scourges upon the just: recurrent famines, plagues and a climatic downturn (the Little Ice Age). ${ }^{7}$ In response to suffering, the late sixteenth century even invented a novel literary genre, the so-called books of consolation (Trostbücher). In consolation for general suffering, they offered Christians justification, purification and eternal life beyond the transience of mortality. Their great success confirms a public desire for consolation.

On the eve of the Thirty Years War, contemporaries became convinced that the current and widespread suffering visited upon true Christians reflected the punishment of God. As an act of appeasement, a strict penitential regime demanded discipline, repentance and campaigns to hunt down the enemies of God. The penitential regime shaped perceptions of suffering throughout the war, when the Empire coincidentally witnessed the worst bouts of witchcraft persecution in its history, especially vicious in the ecclesiastical territories where religion and reason of state closely aligned.

Like Christ, the just suffered at the hands of the unjust for the sins of the few. Their suffering identified them as the people of God, the just. The incarnations of their suffering - such as witches and, in at least one incident, the Jews slaughtered in the Fettmilch uprising in Frankfurt in 1613 on the eve of the war - were tainted through their allegiance to the devil and hence represented in broadsheets with animal traits or as monstrous and less than human. ${ }^{8}$ Suffering demoniacs, twisted, contorted and tortured by Satan, also caught the attention of Europeans at the beginning of the seventeenth century as at no other time before or since.

As a subjectively emotional experience, contemporaries still associated suffering with the Passion - the sufferings of Christ on the cross. Only the just could suffer. In Roman Catholic regions, the resurgence of the cult of the special dead emphasized the sufferings of early Christian martyrs. Heightened interest can be measured in rising numbers of pilgrimages recorded in miracle books; they peaked around this time. ${ }^{9}$ People not only suffered; they were collectively interested in emotional suffering. Indeed, among the catalogue of emotions in German, suffering (Leiden) has a direct etymological link with passion (Leidenschaft), the latter first entering the language from the French in the seventeenth century.

The vocabulary of religious suffering eventually seeped into a novel method of treating souls, psychiatry, with its roots in seventeenth-century works such as René

\footnotetext{
${ }^{6}$ On the instrumentalization of personal suffering for national purposes, see Vera Schwarcz, 'The Pane of Sorrow: Public uses of Personal Grief in Modern China', in A. Kleinman, V. Das and M. Lock (eds.), Social Suffering (Berkeley, 1997), pp. 119-48.

${ }^{7}$ Cultural evidence suggests that contemporaries were well aware of the climatic degradation of the Little Ice Age; see W. Behringer, H. Lehman and C. Pfister (eds), Kulturelle Konsequenzen der 'Kleinen Eiszeit' (Göttingen, 2005).

${ }^{8}$ For an analysis of monstrous images of the human body at the time of the Thirty Years War, see David Lederer, 'Fear of the Thirty Years War', in Michael Laffan (ed.), Fears Past: Emotional Histories, Troubled Times (Princeton, 2011).

${ }^{9}$ D. Lederer, Madness, Religion and the State in Early Modern Europe: A Bavarian Beacon (Cambridge, 2006), pp. 99-119; P. Soergel, Wondrous in his Saints: Counter-Reformation Propaganda in Bavaria (Berkeley, 1993).
} 
Descartes' Les Passions de l'âme, published one year after the end of the Thirty Years War. ${ }^{10}$ Purportedly, the early-seventeenth-century Enlightenment not only ushered in a scientific revolution, but a consonant psychological one as well. ${ }^{11}$ For the nascent psychiatric profession, the passions thereafter became objectified as biological reactions in response to external stimuli acting upon the autonomic nervous system, ostensibly affecting the psyche through the pineal gland. Nevertheless, the novel pathology never rid itself entirely of moral overtones, eventually promoting a modern psychological conceptualization of sufferers as victims of social injustice, such as poverty, crime or war.

The historical profession also accepted a moral characterization of suffering as a manifestation of unjust victimization. Dame Cecilia Veronica Wedgwood's classic portrayal of the Thirty Years War economized neither on words nor in details depicting the horrors of wartime suffering. 'In Germany, the war was an unmitigated catastrophe. In Europe, it was equally, although in a different way, catastrophic'. ${ }^{12}$ Initially published in 1938, Wedgwood's book contrasted the coarse manners of early modern Germany with the nation of culture (Kulturnation) of the nineteenth and twentieth centuries, adopting the contemporary tone of appeasement. Wedgewood painted a reassuringly bleak portrait of a distant, far-off, primitive culture inured to modern sensibilities by an environment of unrelenting violence and cruelty, ostensibly alien to civilized twentiethcentury Germans. Her own moral narrative appeased war nerves by appealing to modern bourgeois sensibilities. By implication, the civilized Germany of Goethe and Schiller diametrically opposed the coarseness of mentality and, arguably, diminished capacity of its desensitized ancestors:

Even in the actual district of the conflict the impact of war was at first less overwhelming than in the nicely balanced civilization of to-day. Bloodshed, rape, robbery, torture and famine were less revolting to a people whose ordinary life was encompassed by them in milder forms. Robbery with violence was common enough in peace-time, torture was inflicted at most criminal trials, horrible and prolonged executions were performed before great audiences; plague and famine effected their repeated and indiscriminate devastations.

The outlook of even the educated was harsh. Underneath a veneer of courtesy, manners were primitive; drunkenness and cruelty were common in all classes, judges were more often severe than just, civil authority more often brutal than effective, and charity came limping far behind the needs of the people. Discomfort was too natural to provoke comment; winter's cold and summer's heat found European man lamentably unprepared, his houses too damp and draughty for the one, too airless for the other. Prince and beggar were alike inured to the stink of decaying offal in the streets, of foul drainage about the houses, to the sight of carrion birds picking over public refuse dumps or rotting bodies swinging on the gibbets. On the road from Dresden to Prague a traveller counted 'above seven score gallowses and wheels, where thieves were hanged, some fresh and some half rotten, and the carcasses of murderers broken limb after limb on the wheels'.

The pressure of war on such a society had to be intensified and prolonged before any popular outcry was evoked, and by then the matter was usually beyond control. ${ }^{13}$

Wedgewood repeatedly fixed the attention of her English-speaking audience on human distress as the real tragedy of the war. Desensitization inured contemporaries to types of

\footnotetext{
${ }^{10}$ Descartes had been a soldier in the war and served with the Catholic League at the Battle of White Mountain. He had his stove experience while he was garrisoned in Neuburg near Ulm prior to the battle.

${ }^{11}$ The term 'psychological revolution' was attributed to Lucien Febvre by Robert Mandrou: see Lederer, Madness, Religion and the State, p. 202, n. 20.

${ }^{12}$ C.V. Wedgewood, The Thirty Years War (London, 1938), p. 525.

${ }^{13}$ Ibid., pp. $13 f$.
} 
suffering later considered unimaginable in civilized twentieth-century Germany. Subsequently, however, in a retrospective foreword to the 1963 edition of her classic study, Wedgewood moderated her initial emphasis on human distress as the central meaning of the Thirty Years War: 'The suffering caused by the Thirty Years War was beyond all reckoning ... But it must also be remembered that the Thirty Years War and its supposed consequences have become a popular myth in German history. ${ }^{14}$ Historic suffering could no longer justify the barbarity of the Nazi dictatorship; Versailles was no justification for the Holocaust; appeasement had been wrong. Intervening events had called progressivism into question.

What brought on her particular unease about the myths of the Thirty Years War? Certainly, modern Germans had, in the interim, proved themselves capable of cruelties as great as or even exceeding those of their ancestors. Doubt in civilized progress led to depictions of the Thirty Years War as the first modern total war, even the real First World War. In his postwar memoirs, Winston Churchill consciously compared the discreet historical époque from 1914 to 1945 (thirty-one years) to the Thirty Years War. ${ }^{15}$ Whether or not we accept the Second World War as a mere a continuation of the First, Churchill's claims illustrate the problems of narrative coherence with which all historians wrestle. They are no less thorny for the seventeenth-century conflict. Chronologically, the expression 'Thirty Years War' has itself been called into question as 'a largely factitious conception which has nevertheless become an indestructible myth'. ${ }^{16}$

For Wedgewood, however, historiographic debate over 'the myth of absolute destruction' is certainly more relevant. ${ }^{17}$ Contemporaries may have perceived the Thirty Years War as an assault perpetrated on innocent Germans by outsiders - 'Croats, Cossacks, Swedes, Finns, Scots, Irish, Hungarians and, less often, French and Spaniards' ${ }^{18}$ Romanticist authors, not least among them Friedrich Schiller in his history of the Thirty Years War and his Wallenstein trilogy, were quick to point out that Germans suffered because they lacked a unified nation state - as did Hitler in Mein Kampf. For Schiller and other romantics, the origins of Germany as a Kulturnation lay in the unifying influence of the German language reified in Luther's translation of the Bible. In Mein Kampf, Hitler vaguely echoed these ideals, but explicitly condemned the cosmopolitan Holy Roman Empire as a weak conglomeration fraught with feuding petty potentates and lacking the unifying essence of blood, thereby resulting in much suffering by the German race.

The first scholarly critique of this 'myth of absolute destruction' originated with a curt dissertation by Robert Ergang in 1956. Ergang attacked the myth of an alldestructive war and his thesis still receives much attention, though it must be said that,

\footnotetext{
${ }^{14}$ C.V. Wedgewood, The Thirty Years War (London and New York, 1989), p. 7.

${ }^{15}$ W. Churchill, The Second World War, vol. 1: The Gathering Storm (London, 1949), p. ix. A. Kramer mentions these allusions in the conclusions to his Dynamic of Destruction: Culture and Mass Killing in the First World War (Oxford, 2007). See also H.U. Wehler, Deutsche Gesellschaftsgeschichte 1914-1949, vol. 3 (Munich, 2003), p. 1168—many thanks to Alan Kramer for these references.

${ }^{16}$ Asch, The Thirty Years War, pp. 2f., quoting Nicola Sutherland. In fact, as Konrad Repgen had previously demonstrated in a number of articles ignored by Sutherland, the expression was commonly employed by contemporaries, who recognized the historical coherence of the struggles from 1618 to 1648.

${ }^{17}$ Wilson, The Thirty Years War, p. 779.

${ }^{18}$ Ibid., p. 780.
} 
apart from a few provocative statements, his forty-page work is based on slight research and is indicative of a post-1945 reaction to historical claims of German suffering based on the Thirty Years War. ${ }^{19}$ Detailed analyses took up his theme as a starting point. For example, historians note that while the conflict devastated large areas of central Europe, many others escaped entirely unscathed. Hamburg is a classic model in that regard; it remained largely undamaged by the war and secured its economic future as a weapons transshipment depot, alternately supplying conflicting parties during the course of the conflict. ${ }^{20}$

Günther Franz scrutinized the regional specificity of suffering in his 1940 study of the Thirty Years War and the German folk. It went into a fourth edition as late as 1979. ${ }^{21}$ Franz is an enigmatic figure. Along with those of Ergang, his findings provided Wedgwood with sufficient reasons to pause in her own postwar edition. On the one hand, Franz's analysis was based on solid source-based research. On the other, Franz was a convicted Nazi and his results are heavily compromised by the National Socialist political agenda. He was among the first professional historians to join the Nazi party on 1 May 1933; five months later, he joined the SA and, in 1935, the SS as Group Leader (Rottenführer) in the Central Racial and Settlement Bureau (Rasse- und Siedlungs-Hauptamt, RuSHA). Posted as ordinary professor to Jena in 1937, he rose through the ranks of the SD and SS to become SS Captain (Hauptsturmführer).

A politically astute and powerful academic, over six feet tall, Franz cut an imposing figure at the national conference of German historians (Historikertag) in Erfurt in 1937, when he appeared in full SS regalia. At Jena, in order to avoid confusion with his associate, the racial scientist Hans Günther (with whom he continued to maintain ties after the Second World War), Franz, the agrarian historian, became known collegially as 'peasant Franz' ('Bauern-Franz') in order to differentiate him from 'racial Franz' ('Rassen-Günther'). ${ }^{22}$ He answered the call to a chair for Reformation history and the Thirty Years War at the newly reorganized Reichsuniversität of Strasbourg in $1941 .{ }^{23}$ Franz received a positive promotional recommendation from Reinhard Heydrich and, eventually, assignments as primary investigator on teams for historical research into agrarian history and the history of witchcraft from Heinrich Himmler. He helped organize a conference at Wannsee on research on enemies of the state (Gegnerforschung) in October 1942. It is fair to say that Franz, an avowedly politicized historian, acted as a vocal intellectual mouthpiece of the National Socialist regime. Censored after the war, his assertive academic engagement proved uncontainable and, with the help of social networks, Franz was rehabilitated and posted as professor for agrarian history at Stuttgart-Hohenheim, where he served as rector from 1963-1967. He died peacefully, aged ninety, in 1992.

\footnotetext{
${ }^{19}$ R. Ergang, The Myth of the All-Destructive Fury of the Thirty Years War (Pocono Pines, 1956).

${ }^{20}$ G. Parker (ed.), The Thirty Years War (London, 1984; 2nd edn 1997); J.V. Polišenský, War and Society in Europe 1618-1648 (Cambridge, 1978).

${ }^{21}$ G. Franz, Der Dreißigjährige Krieg und das Deutsche Volk: Untersuchungen zur Bevölkerungs- und Agrargeschichte (Jena, 1940).

22 Ibid., p. 118.

${ }^{23}$ W. Behringer, 'Bauern-Franz und Rassen-Günther: Die politische Geschichte des Agrarhistorikers Günther Franz (1902-1992)', in W. Schulze and O.G. Oexle, Deutsche Historiker im Nationalsozialismus (Frankfurt/Main, 2000), pp. 114-41.
} 
Franz undertook several technical studies of German agrarian history which laid the groundwork for future generations of researchers working on, among other topics, the German Peasants' War of 1525 and the Thirty Years War. His promulgation of the political philosophy of Lebensraum informed his research interests, which subsumed disciplined scholarly analysis within the framework of National Socialist strategic policy.

Franz's archival research revealed that the vast majority of civilian casualties during the Thirty Years War resulted from famine and plague and only indirectly from military campaigns. However, he explicitly compared these to deaths from the flu epidemic at the end of the First World War resulting from the so-called 'starvation' blockade (Hungerblockade) of Germany by the allies, which 'weakened the Volkskörper, rendering it less resistant' to disease. In other words, the German civilian population had been victimized by Allied strategy and unjustly made to suffer as an indirect consequence of the First World War. ${ }^{24}$

Franz calculated that actual combat losses in the Thirty Years War (reckoned at between 325,000 and 338,000 soldiers) 'were never all too large'. In accordance with the bellicose policy of Lebensraum, Franz downplayed battle casualties. Demographically, he suggested, these could easily have been compensated by a healthy policy of population management. As evidence, he noted the resilience of the Swiss cantons, which recovered quickly from the catastrophic plague of $1628 / 29$, and that in Bohemia, the peasant population declined by only $17 \%$, from 150,000 to 124,000 , 'therefore, a relatively small number'. Overall, for Franz, the role of combat casualties in the strategic arena of a grand war was relatively insignificant and potentially sustainable.

Nonetheless, Franz was unwilling to let go of the myth of an all-destructive war entirely. He simply needed to relocate the source of destruction from the combatants onto another source, one which not only vindicated war as an instrument of foreign policy, but also demonstrated an inimical fifth column, an internal academic enemy that prejudiced German history. That source was Jewry. In his introduction, he castigated the historian Robert Hoeniger, among the first to challenge the myth of an all-destructive war. According to Franz, Hoeniger vastly underestimated the cultural destruction of the Thirty Years War (Hoeniger estimated total casualties at only 5\% and did not take casualties from disease into account). Franz intimated that Hoeniger's off-hand remarks on the expropriation of the wealth of the German people (Volksvermögen) by the Jews underplayed the insurgent force of this critical internal enemy. He further attacked both Hoeniger and the 'Jew' historian Hugo Preuss for rationalizing the results of the war as a natural outcome of conjunctural factors, such as long-term economic and cultural decline, as well as misunderstanding the significant role of political (racial) disunity in the Empire. ${ }^{25}$

Subsequent regional and local demographic studies have since upheld Franz's research on several critical points; suffering varied greatly from region to region, from

\footnotetext{
${ }^{24}$ Franz, Der Dreißigjährige Krieg, pp. $14 \mathrm{f}$.

${ }^{25}$ Wilson, The Thirty Years War, pp. 780f: 'Played out against the backdrop of renewed destruction during the First World War, this debate divided opinion into what have become known as the 'Disastrous War' and the 'Early Decline' schools. Whereas the former propagated the received wisdom of Germany as innocent victim, the latter countered by arguing the Thirty Years War merely accelerated existing problems stemming from overpopulation and a reorientation of Europe's economy towards the Atlantic seaboard in the late sixteenth century.'
} 
town to town, indeed from village to village. Compared to the First and Second World Wars, most casualties did indeed occur only indirectly from human violence, brought on by famine and, above all else, disease. However, his general prognoses on the comparative demographic sustainability of war as strategic policy have proved less accurate. In terms of a percentage of the prewar population, Peter Wilson has compiled a sobering statistical comparison of overall casualties in the great wars, based on the most recent evidence: 1939-1945: 6\% (Europe); 1914-1918: 5.5\% (Europe); 1618-1648: 20\% (Holy Roman Empire). ${ }^{26}$ The mechanics of demographics functioned very differently from the way presupposed by Franz's expansionist concept, with contingencies that his racial model proved incapable of explaining.

\section{II: The Rape of Madgeburg, or 'Do Historians Create Historical Suffering'?}

No matter how shocking demographic statistics appear as black-and-white facts, they still leave us to measure suffering subjectively as an emotional quality of human experience - an endeavour fraught with methodological difficulties beyond qualitative issues. Thus far, we have considered historiographic problems of suffering in respect of the changing perspectives of historians. These are further compounded by the hermeneutics of interpreting experientially expressed subjectivity. Specifically, to what extent can we measure suffering when contemporary depictions are not only wildly individualistic (involving understatement, overstatement or blatant contradictions), but also expressed in a value-coded language distant from our own modern experience? How can we translate the undoubtedly real experience of German suffering during the Thirty Years War into a meaningful narrative?

To illustrate these difficulties, we might examine one specific type of wartime suffering - rape. Surprisingly little has been written on the history of rape during the Thirty Years War. ${ }^{27}$ We know far more about subjective experiences of pillaging, theft and torture suffered by civilian populations at the hands of soldiers. Research on rape is not only hampered by a paucity of direct references, but also the opacity of language in anecdotal and circumstantial evidence. However, these difficulties in fact represent interpretative keys to unlock general experiences of suffering during the Thirty Years War.

Immediately, we confront the nagging juxtaposition of rape as a unique cultural construction versus the value of universal human rights. Contemporaries certainly agreed with us that rape, per se, was wrong and a crime. However, normative sources alternate between satirical equivocations and partisan outrage, both predicated upon a misogynist moral high ground which was, in essence, a male preserve. A brief, but thick description of the most destructive siege of the war, 'The Destruction of Magdeburg' (excidium Magdeburgense) of 1631, offers clues to a broader contextualization of early modern attitudes towards rape, bringing an oft-hidden form of suffering into sharper contrast.

\footnotetext{
${ }^{26}$ Wilson, The Thirty Years War, p. 787. The absolute figures for casualties are, of course, contradictory, owing to the comparison of regional and supra-regional geographic units (i.e., the Empire to Europe), respectively in millions of deaths, including disease: $33.8 ; 27 ; 5$.

27 On soldiers and rape during the War, see J. C. Theibault, 'Landfrauen, Soldaten und Vergewaltingungen während des Dreißigjährigen Krieges', Werkstatt Geschichte, 19 (1998), pp. 25-39. For a comprehensive attempt at a general cultural history of modern rape, see J. Bourke, Rape: A History from 1860 to the Present (London, 2007).
} 
Hans Medick opens a recent interpretation of the siege by generally questioning the creation of historical meaning: do historians decide which events deserve historical status, are events already elevated to the status of 'historical event' by contemporaries, or are some events cemented in their historical significance before they happen? ${ }^{28}$ Observers on both sides, Catholic and Protestant, certainly perceived the destruction of Magdeburg as a momentous event. However, their attention was drawn to the city as much by the cataclysmic flames engulfing it in 1631 as by its long-standing image as a Lutheran stronghold. Magdeburg held out against two prior siege attempts (1550/1 and 1629) by imperial forces. Magdeburg flaunted herself historically and was thus destined to be a military target of primary ideological importance. When the fall finally came, it proved a devastating blow to the Protestant cause. By contemporary estimates, the destruction of this centre of evangelical resistance cost over 20,000 civilian lives. Many died in the accompanying conflagration and, in blood-lust, Imperial troops even butchered pro-Hapsburg sympathizers during their abortive attempt to surrender to Tilly's victorious army. ${ }^{29}$

The media immediately latched onto the siege as one of the major events of the war. Strangely (for us perhaps), media attention contorted the siege into a gender-laden forest of symbols. Military terminology had long spoken of a successful siege as a penetration. However, images of the ravishment of Magdeburg were harnessed for propagandistic purposes by both sides and became the theme of numerous broadsheets. Media treatment of the siege played upon a number of contemporary gender assumptions. The coding of female attributes to cities (die Stadt) was especially poignant in this case, given the town's name (Magd is a maid or virgin) and the fact that imperial troops had never entered her before. Several broadsheets projected the relationship between conqueror (Tilly) and conquered (Magdeburg, the virgin maid) in terms of a courtship with sexual overtones all-too-familiar to early modern Europeans. For example, one pro-Habsburg broadsheet depicted the siege as a mirthful banquet attended by all the estates of the Empire; the maiden, bedecked with a virginal garland, wisely chooses the Emperor over the Protestant leaders as her dancing partner (Figure 29.16).

The accompanying text even offered a jaunty nuptial sing-along to a popular tune of the war, the Schecken. ${ }^{30}$ Similarly, the Magbeburg Marriage Song, another mnemonic lyric, describes Tilly, Pappenheim and their forces suavely wooing the maiden Magdeburg in

\footnotetext{
${ }^{28} \mathrm{H}$. Medick, 'Historical Event and Contemporary Experience: The Capture and Destruction of Magdeburg in 1631', History Workshop, 52 (2001), pp. 23-48.

29 Protestant Magdeburg had already withstood Catholic sieges in the Schmalkaldic War and in 1629, so it was viewed by Unionists as impenetrable, by Tilly and other Catholic leaders as a 'Centre of Evil' (Centrum mali). Contemporary estimates of casualties range from 20,000 to 60,000 , though the latter figure-probably larger than the town's original population -is surely fantasized: see H. Medick, 'Historisches Erreignis und zeitgenössische Erfahrung: Die Eroberung und Zerstörung Magdeburgs 1631', in Krusenstjern and Medick, Zwischen Alltag und Katastrophe, pp. 377-408; Michael Kaiser, '“Excidiu Magdeburgense”: Beobachtungen zur Wahrnehmung und Darstellung von Gewalt im Dreißigjährigen Krieg', in M. Meumann and D. Niefanger, Ein Schauplatz herber Angst: Wahrnehmung und Darstellung von Gewalt im 17: Jahrhundert (Göttingen, 1997), pp. 43-64.

${ }^{30}$ A useful explanation of the Schecken, to include reference to the Liedflugblatt in question here, is available at www. accordsnouveaux.ch/de/DownloadD/files/Scheckenlied_Nehlsen.pdf (accessed 10 June 2011). On the general theme of fear and suffering in contemporary Evangelical songs, see Hartmut Lehmann, 'Not, Angst und Pein': Zum Begriff der Angst in protestantischen Kirchenliedern des späten 16. und des frühen 17. Jahrhunderts'", in Lehmann (ed.), Transformationen der Religion in der Neuzeit Beispiele aus der Geschichte des Protestantismus (Göttingen, 2007), pp. 297-310.
} 


\section{Ein Retwe Sied.

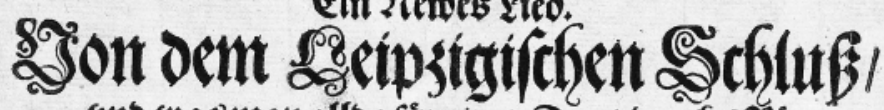

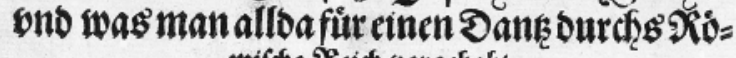 miftese भieid) vorgeb̧abt.}

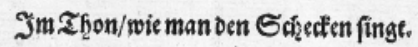

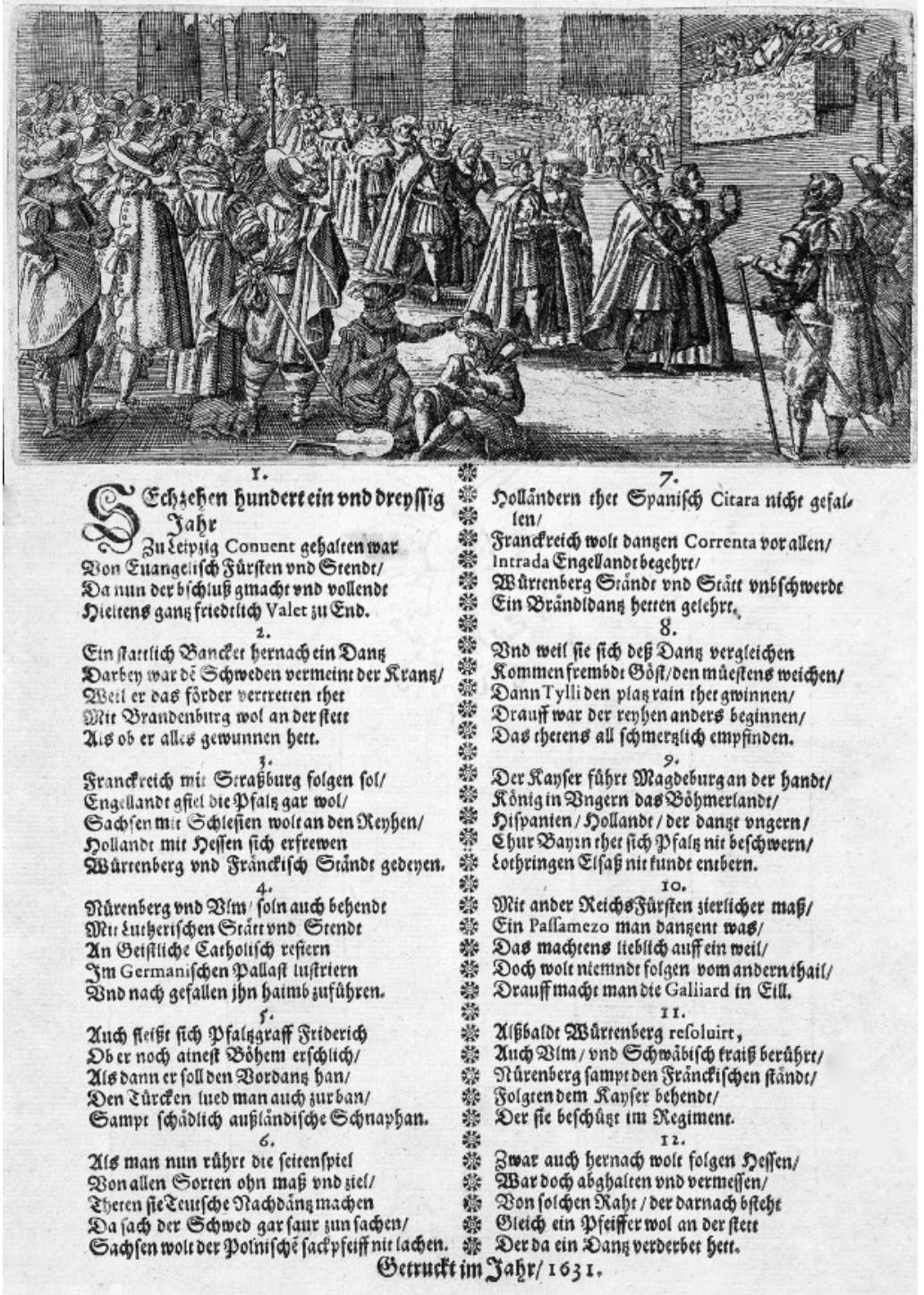

Figure 29.16: Ein Newes Lied von dem Leipzigischen Schluß: pro-Catholic lampoon, in which the maiden Magdeburg 'wisely' chooses to dance with the emperor rather than with any Protestant leaders.

Wolfenbüttel, Herzog August Bibliothek: IH 159. 
the language of a courtship ritual in a bid to win her hand (Figure 29.17). The powers of Europe offer comments, while stubborn Magdeburg unjustly holds out for the King of Sweden. She is warned by the Emperor, the Empire and God to desist from her course.

Less complimentary to the Empire, the author of the Capitulations bluntly lampoons Tilly's impatient marriage demands made against the Protestants; Ulm should provide the dowry, Strasbourg the consummation-monies (Morgengabe), the King of Sweden should give the bride away and the wedding should be held in Nuremberg (Figure 29.18).

In an even more vehement anti-Hapsburg broadsheet, the Maiden is shown suffering, half-clad and vulnerable, portrayed in her convalescent bed, vainly pleading with the King of Sweden and the Protestant princes to save her from the Emperor, Marshall Tilly and his rapacious soldiers. ${ }^{31}$ In its penultimate anti-Hapsburg form, yet another broadsheet illustrates Magdeburg lamenting the loss of her maid's wreath, taken by a menacing Tilly and signifying the loss of her virginity at the hands of the Catholic forces. In a conscious comparison with the rape of Lucretia, Magdeburg pines that although

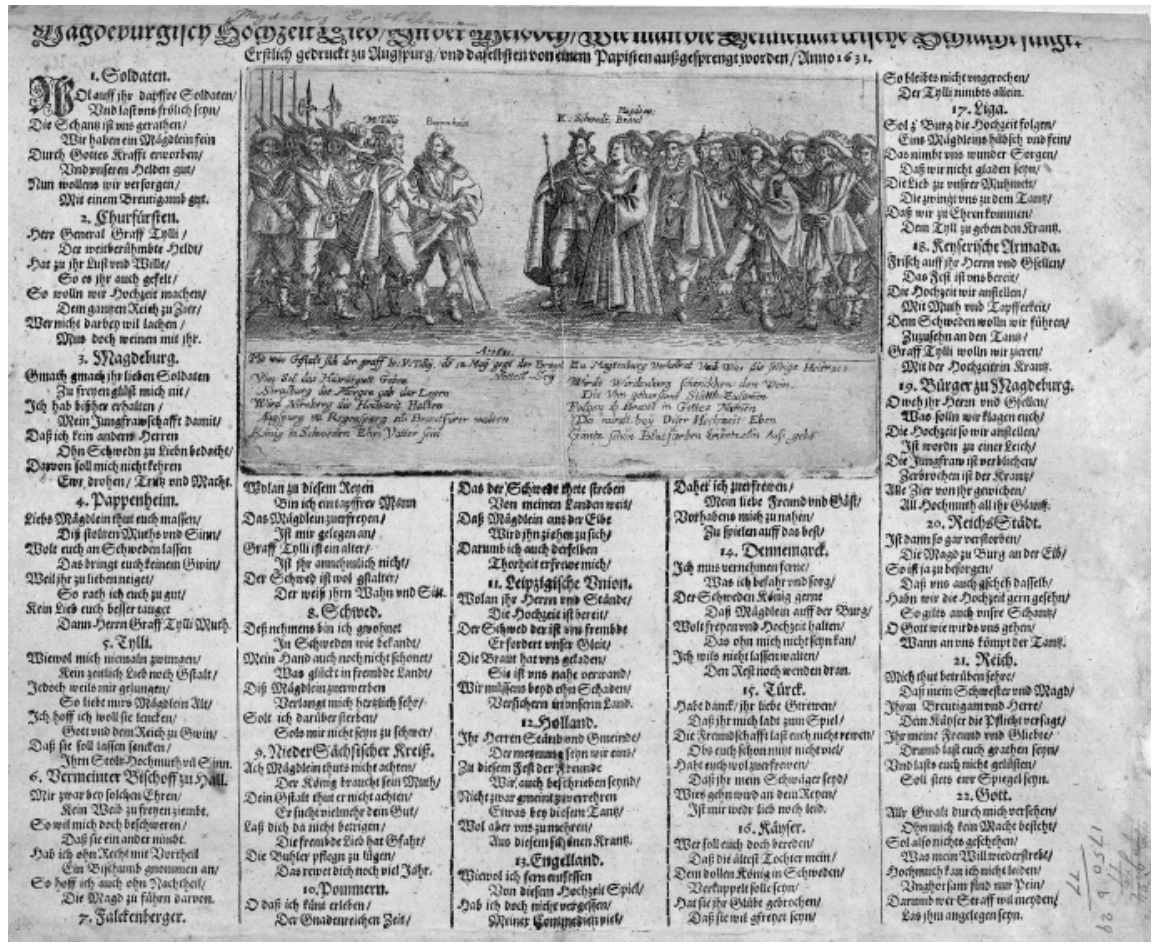

Figure 29.17: Magdeburgische Hochzeit Lied: satirical song about Tilly's courtly wooing the maiden Magdeburg.

London, British Library 1750b29[77].

31 John Roger Paas, The German Political Broadsheet 1600-1700, vol. 5: 1630-1631 (Wiesbaden, 1996), p. 137: Junckfrawlicher Unmueth/ unnd KlagRueff/ vom verspochne Hilff zu ihren Asistenten. 


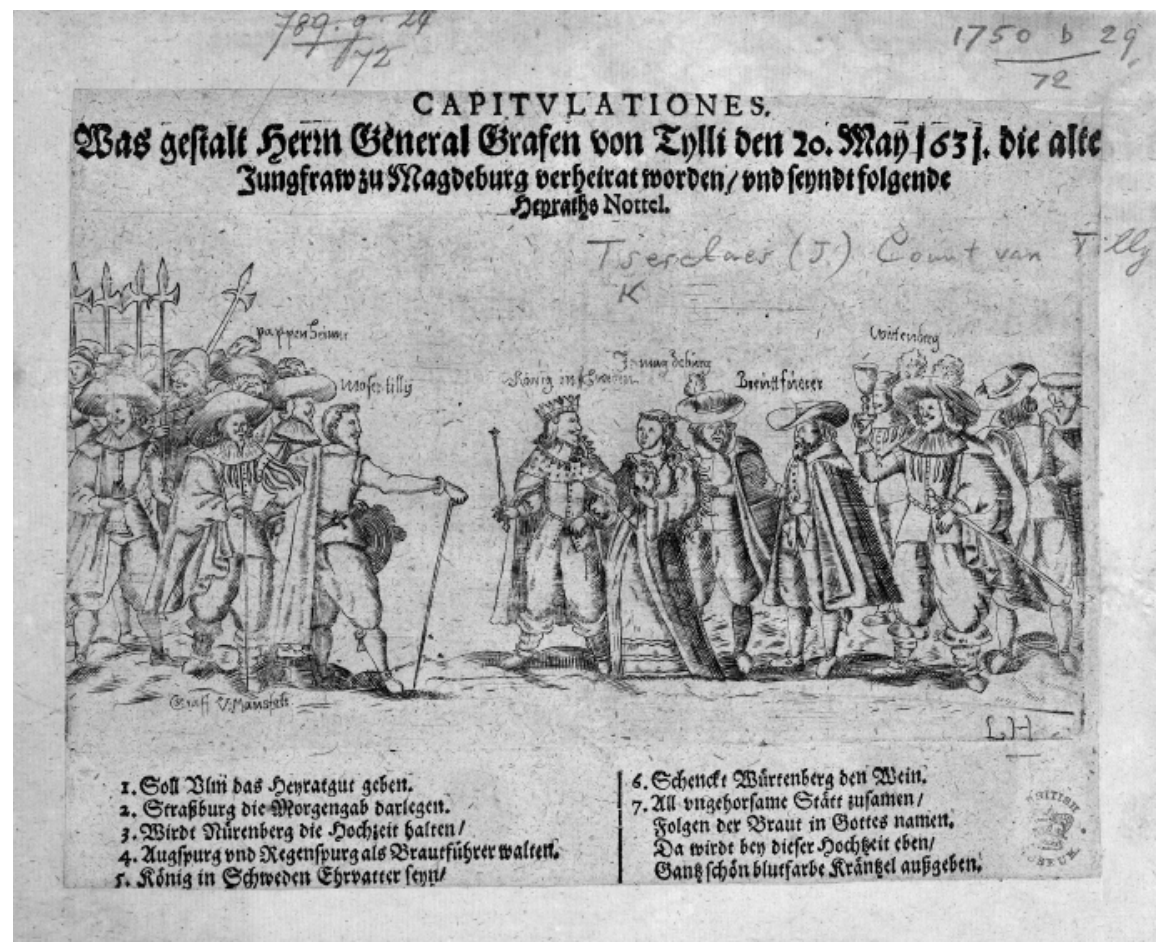

Figure 29.18: Capitulationes: Lampoon about Count Tilly's heavy matrimonial demands for his marriage to the maiden Magdeburg.

London, British Library 1750b29[72].

her physical honour has violently been taken from her, she swears she resisted and the honour of her soul remains intact. She swears she loves another and swears the wreath to him. Meanwhile, Tilly offers up carnage in the form of human flesh and blood at his wedding celebration (Figure 29.19).

Personal honour assumed a level of physicality in early modern Europe which is complex and difficult for us to comprehend. Like distinctions in a caste system, social dishonour was legally tantamount to a material stain on the human body, rendering it impure. ${ }^{32}$ Female honour and virtue (in so far as women could have virtue, primarily a male quality) remained highly contingent upon sexual comportment in a patriarchal society. Generally, the loss of virginity through fornication or proven charges of promiscuity and adultery translated into a loss of honour, manifest in Hawthorne's Scarlet Letter. ${ }^{33}$ The male population of Magdeburg equated the defence of their city to the defence of their female kin from the dishonour of violation, while the Catholic besiegers

\footnotetext{
32 On the nature of honour as a physically palpable quality in early modern Germany, see K. Stuart, Defiled Trades and Social Outcasts: Honor and Ritual Pollution in Early Modern Germany (Cambridge, 2000).

${ }^{33}$ Though neither defloration nor illegitimate children necessarily precluded marriage.
} 


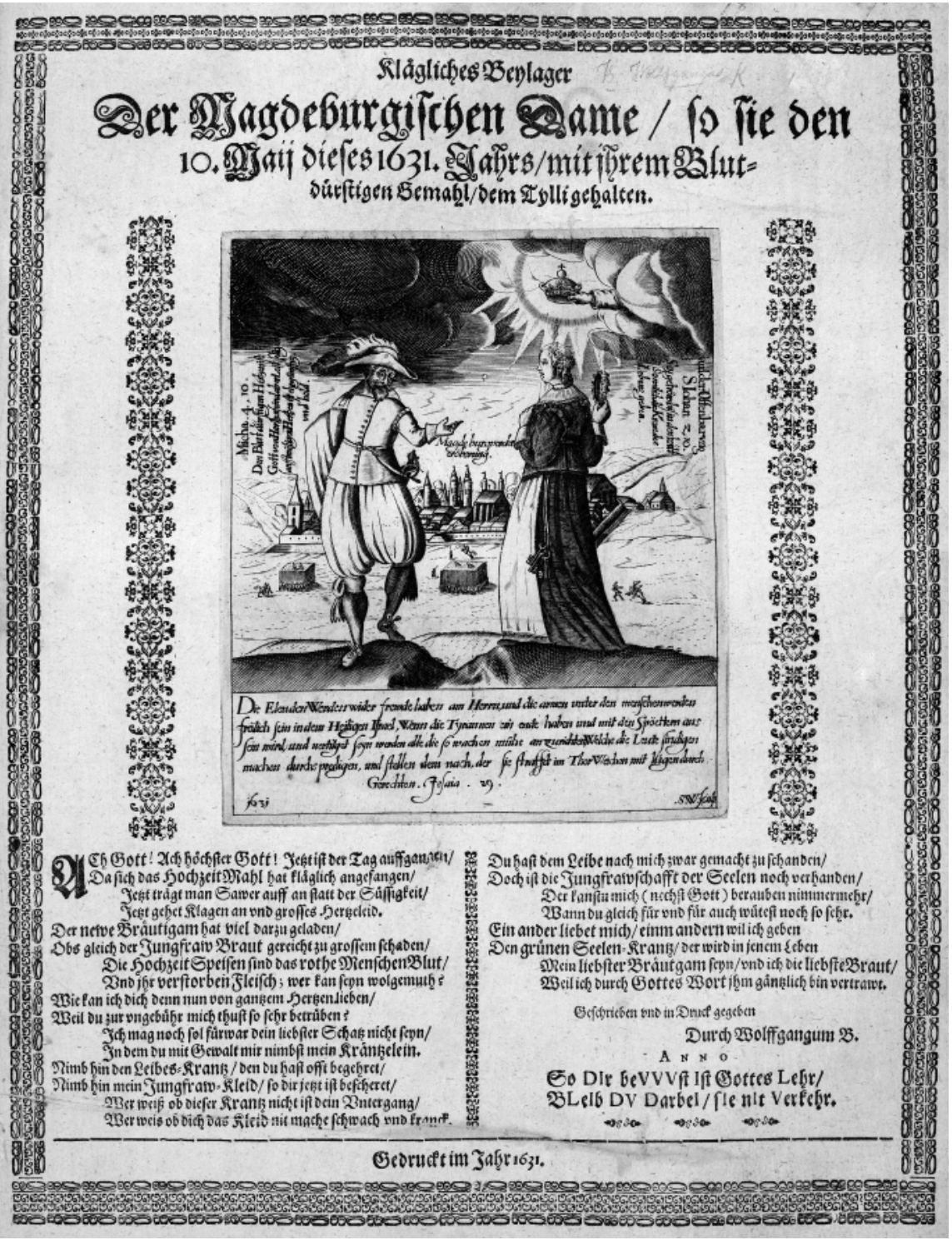

Figure 29.19: Klägliches Beylager: Anti-Imperial lampoon, in which the maiden Magdeburg laments her rape by Count Tilly.

London, British Library 1750b29[78].

envisioned Protestant Magdeburg as a wench who had flaunted herself and got what she deserved. Siege was dually represented in the broadsheets as a test of virility, to 'take' or 'defend' female honour.

Research conducted on early modern trials for fornication and claims brought before marriage courts highlights common courtship rituals cited as stains on the honour of 
women, including charges of broken marriage proposals. ${ }^{34}$ Acceptance to dance at peasant celebrations was taken as an indication of willingness on the part of a woman to enter into marriage negotiations. Other common rituals included a male offer and female acceptance of a shared drink of beer, a token gift or coins. Such approaches were generally followed by wooing, literally known as 'windowing': nocturnal visitations reminiscent of the balcony scene in Romeo and Juliet. The man appeared with gifts at the window, offering words of praise or a song. If the woman invited him in, it was presumed they would sleep together chastely-although charges of impregnation brought at marriage courts indicate the contrary. One historian translates the culmination of these rituals into modern terms with the expression 'rape-like'. ${ }^{35}$ Legally consummated, clandestine marriages included formal negotiations to establish a dowry. Initially an innovation of the evangelical reform, the modern public marriage ceremony - intended largely to protect the property rights of parents - still had not entirely penetrated this level of popular culture. ${ }^{36}$ Although often challenged as a highly fictionalized account, here Jacob von Grimmelshausen's Simplicissimus is of remarkable anecdotal value in ethnographic terms, as he relates several stories of many such popular rituals, usually with a wry sense of peasant irony. Only the fact that the ritual context was familiar to his readers can explain the popularity of his work among survivors of the war years. ${ }^{37}$

Notably, while woman often brought charges of broken marriage promises before ecclesiastical courts, remarkably few actual cases of rape appear in criminal records, either in war or peacetime. Rape is highly emotional, terribly difficult to prove and socially disruptive; in the early modern period, accusations of rape were likely to taint the honour of the accuser as much as that of the accused rapist. Such attitudes were more than mere wink-and-nod aspects of patriarchal culture, they were enshrined in law. Cases of forced carnal relations often fell under the general rubric of defloration, a charge usually taken up by women to regain their honour, to force would-be suitors to marry or to seek compensation for loss of virginity (a shoe was a common token accompanied by a fine).

Further, as Ulinka Rublack points out, a Württemberg rescript of 1646 required victims of rape by billeted soldiers to bring the crime to the attention of their pastor or family within one month. ${ }^{38}$ Otherwise, as the law explicitly stated, unmarried women, widows and abandoned wives might otherwise later determine they were pregnant and try to claim rape simply to cover up simple fornication. Therefore, charges brought after the thirty-day period met with an automatic conviction for fornication and four weeks imprisonment, while women who claimed impregnation by soldiers faced banishment. Draconian legal proscriptions such as these surely dampened the resolve of women

\footnotetext{
${ }^{34}$ See, for example, M. Safley, Let no Man put Asunder (Kirksville, 1984).

${ }^{35}$ S. Breit, 'Leichtfertigkeit' und ländliche Gesellschaft: Voreheliche Sexualität in der frühen Neuzeit (Munich, 1991), p. $217 f$.

${ }^{36}$ T. Robisheaux, Rural Society and the Search for Order in Early Modern Germany (Cambridge, 1989).

${ }^{37}$ One of the weaknesses of Ergang's argumentation is his attack on Grimmelshausen based on its basis in fiction, which ignores its ethnographic and autobiographic significance. He also refers to superlative accounts of the effects of plague as exaggeration, pp. $4 \mathrm{ff}$.

${ }^{38}$ Rublack's 'Wench and Maiden: Women, War and the Pictorial Function of the Feminine in German Cities in the Early Modern Period', History Workshop Journal, 44 (1997), pp. 1-21, here p. 16, offers a fine analysis of rape.
} 
openly to accuse their attackers. By detaching women from their network of social support, such laws left countless victims with little option other than to join the ranks of camp followers and seek support from the soldiers. Generals willingly employed these experienced 'soldiers' (that is, women and children), despite the additional logistical burdens caused by the presence of their partners and offspring, thus adding to the weight of wartime contributions exacted from local communities in a vicious circle. ${ }^{39}$ The more soldiers took from local communities, the more they were required to take; suffering among the civilian population increased in arithmetic proportion.

We do have eponymous examples of female warrior-heroes who not only defended their honour, but their cities as well. We should not take these at face value, however, but instead as a topos to exhort men to greater valour by challenging their sense of virility. They were part of the broader picaresque genre of transvestite women warriors which, like the Simplicissimus and Courache traditions, trace their genealogy to Golden Age Spanish literature. ${ }^{40}$ Helen Watanabe-O'Kelly has recently examined this tradition for Germany, noting both positive and negative perspectives on the image of the woman warrior. ${ }^{41}$ Certainly, such portrayals encouraged male citizens not to be outdone in the defence of the honour of their city or their womenfolk and to offer up the ultimate sacrifice opposing the penetration of the town walls by the enemy or rival, another fear superimposed from popular attitudes towards courtship and cuckold marriages.

The story of Gesche Maiburg (also called Gesche Magdeburg), is one such example also noted by Rublack. Gesche reportedly helped defend the city of Braunschweig during a siege in the summer of 1615, three years before the start of the Thirty Years War. Contemporary images represent her as a virtuous maid sporting a virgin's wreath not unlike the civic coat of arms of Magdeburg, in addition to the transvestite accoutrements of a professional male soldier. ${ }^{42}$ Her image adorned a number of woodcuts celebrating the Braunschweig siege, reappearing during the Thirty Years War. These images casually associated her with the previously successful defences of Magdeburg.

Heroic as such legends are, they tend exaggerate the lot of civilian women in wartime. For example, an interpretation of women valiantly choosing death over dishonour misinterprets the standard Christian dispute over the Lucretia legend, based on St Augustine's arguments against female suicide in The City of God. And, in fact, an actual case of any woman killing herself to avoid rape during the Thirty Years War has yet to be discovered. As humanists familiar with the original Roman legend knew well, Lucretia committed suicide after suffering rape. In 1632, an anonymous chronicler reported the suicides of two nuns in Augsburg, who killed themselves after Swedish soldiers raped

\footnotetext{
${ }^{39}$ Wilson, The Thirty Years War, p. 828.

40 Other legends include the Hungarian women who defended Eger against the Turks in the sixteenth century and the picaresque tale of Catalina de Erauso, the transvestite lieutenant nun who apparently escaped the convent to a life of swashbuckling adventures in the New World. On women acting as men, see R.M. Dekker and Lotte C. van de Pol, The Tradition of Female Transvestism in Early Modern Europe (London, 1989).

${ }^{41}$ As she points out, 'the number of artistic depictions of women warriors stands in inverse proportion to the participation of actual women in war. But then, it also stands in inverse proportion to the participation of women in the public sphere in Germany in general': H. Watanabe-O'Kelly, Beauty or Beast? The Woman Warrior in the German Imagination from the Renaissance to the Present (Oxford, 2010), p. 6.

42 Rublack, 'Wench and Maiden'.
} 
them. ${ }^{43}$ Taking one's life in despair (denying one's hope of salvation, a form of apostasy) was a heinous sin committed at the direct behest of the devil and virtually assuring damnation. One had to be desperate indeed to face that divine penalty. Most theologians, Protestant and Catholic, insisted it was far preferable to suffer the corruptions of rape rather than risk the immortal soul.

The theme of institutionally sanctioned rape in wartime is a nearly universal topos, as we know from Bosnia and Africa (and perhaps Soviet-occupied Germany during the Second World War), with the genocidal intention of breeding out the enemy. However, as yet, no evidence has been uncovered to suggest that any of the belligerents in the Thirty Years War ever consciously promoted an institutionalized policy of rape against the civilian population. For example, although the Swedish ambassador embellished his description of the horrors of the sack of Magdeburg with the vague accusation that '.. wives and daughters were tied behind the horses, dragged into camp, raped, and terribly molested' he blames foreigners (Croats and Walloons) for the atrocities or compares the perpetrators to 'Turks, Tartars and heathens', rather than intimating a direct order from Tilly. ${ }^{44}$

Nonetheless, there is sufficient anecdotal evidence to indicate that rape was common. If it was more common than official sources wish us to believe, then this is certainly due to contemporary values which encouraged the taking of prizes as a reward to besieging soldiers, as well as a propensity to dehumanize the enemy as an act of self-righteous revenge. Nonetheless, discipline was swift and harsh in early modern armies and clearly not all soldiers were potential rapists. A handful of cases taken against English mercenaries for raping civilians in Sweden before their transfer to the continent verify not only how the effects of war extended far beyond the field of battle, but also ultimately how serious authorities were about keeping discipline among their troops. ${ }^{45}$ Justice could be swift and severe, when applied. Indeed, it has been argued that soldiers suffered as much if not more than civilians during the Thirty Years War. ${ }^{46}$

\section{III: Suffering, Experience, Memory and the Struggle for Order}

Rape is just one example of the interpretative problems facing historians when analysing suffering. Leaders needed to balance restraint with inevitable breakdowns of discipline on the ground and invariably maintained morale through tacit collusion. This leaves us to consider, both theoretically and methodologically, how best to fill in other grey areas of suffering glossed over in the media, official reports and normative legal sources. In order to better evaluate other types of suffering, historians of the Thirty Years War

\footnotetext{
${ }^{43}$ Stadtarchiv Augsburg, Reichschronik 27; see also, D. Lederer, "'Wieder ein Fass aus Augsburg . . .": Suizid in der frühneuzeitlichen Lechmetropole', Mitteliungen: Institut für Europäische Kulturgeschichte der Universität Augsburg, 15 (2005), pp. 47-72.

${ }^{44}$ T. Helfferich and P. Sonnino, 'Civilians in the Thirty Years' War', in L.S. Frey and M.L. Frey (eds), Daily Lives of Civilians in Wartime Europe, 1618-1900 (Westport, Ct, and London, 2007), pp. 23-58.

${ }^{45} \mathrm{~K}$. Jansson, 'Soldaten und Vergewaltigung im Schweden des 17. Jahrhunderts', in Krusenstjern and Medick, Zwischen Alltag und Katastrophe, pp. 195-225.

${ }^{46}$ Ronald G. Asch, " "Wo der soldat hinkömbt, da ist alles sein": Military Violence and Atrocities in the Thirty Years War Re-examined', German History, 18 (2000), pp. 291-309. The image seems to confirm Diane Wolfthal's suggestion that the corpses depicted in Callot's Hanging Tree had been soldiers, in Wolfthal, 'Jacques Callot's Miseries of War', The Art Bulletin, 59 (1977), pp. 222-33, esp. p. 224.
} 
rely increasingly upon personalized accounts of subjective experiences. Their allies are the proliferation of self-reflective and autobiographical sources during the seventeenth century, such as diaries, household records and correspondence, all indicative of higher rates of literacy and a heightened mood of religious introspection. Recent efforts at cataloguing and analysing hitherto under-utilized sources greatly enrich our current understanding of the quotidian impact of the war. The interpretation of personal experiences recorded by ordinary people has come to occupy an important, yet controversial role in the current historiography of the Thirty Years War.

Interpretative controversy revolves around two related issues, one theoretical, the other methodological. Theoretically, early modern historians distinguish between two forms of experience: Erlebnis, the fleeting, unrelated and individualized experience of lived events recorded in a stream of consciousness; and Erfahrung, a more reflective process of accumulating and selecting particular experiences to constitute a comprehensive narrative. Debate over both interpretative positions appears in special editions of the Historische Zeitschrift (2001) and, most recently, German History (2010). ${ }^{47}$ Critique of the former (Erlebnis) includes its reliance on a high level of microhistoric experiential individuality; of the latter (Erfahrung), that its content is usually guided by intentionality or a partisan master narrative. Both categories test the tensile limits of the relationship between the individual and the collective consciousness as a useful framework for historical analysis.

Not surprisingly, the classification of sources as more or less suited to explore that relationship breaks down along these two schools of thought, though there has been much productive interchange between them. Methodologically, the wider net is cast by promoters of Erlebnis, who operate with a broad spectrum of sources known as egodocuments. In German historiography, Winfried Schulze developed upon the concept of ego-documents originated by two Dutch historians, Jacob Presser and, subsequently, Rudolf Dekker. ${ }^{48}$ Ego-documents subsume a wide array of source documentation, from the personal and autobiographical to the official, such as eye-witness testimonies, physicians' case files or interrogation records extorted through torture. Supporters of the methodologically stricter Erlebnis approach, including Benigna von Krusenstjern and, to a lesser extent, Kaspar von Greyerz, limit themselves to self-produced testimonies recorded over a longer period of time (Selbstzeugnisse) as truer representations of subjective experience. ${ }^{49}$ Major collection projects on ego-documents and Selbstzeugnisse have been under way for some time in several European countries (led by Dekker in Holland and Greyerz in Switzerland). A notable increase in publications is currently supported by a dedicated series, Selbstzeugnisse der Neuzeit.

Of particular interest for historians of the Thirty Years War is the recent work of Geoffrey Mortimer, who builds upon a regional study by John Theibault to produce a

\footnotetext{
${ }^{47}$ Historical experience is the subject of a dedicated Beiheft of the Historische Zeitschrift: P. Münch, 'Erfahrung' als Kategorie der Frühneuzeitgeschichte (Munich, 2001); ego-documents as historical sources are considered in a special edition of German History, 28 (2010). The issues are laid out briefly in Wilson, The Thirty Years War, pp. $822 \mathrm{ff}$.

${ }^{48}$ W. Schulze (ed.), Ego-Dokumente: Annährerung an den Menschen in der Geschichte (Berlin, 1996).

${ }^{49}$ A programmatic contribution is that of Benigna von Krusenstjern, 'Was sind Selbstzeugnisse? Begriffskritische und quellenkundliche Überlegungen anhand von Beispielen aus dem 17. Jahrhundert', Historische Anthropologie: Kultur, Gesellschaft, Alltag, 2 (1994), pp. 462-71; and, most recently, the volume by K. von Greyerz, Selbstzeugnisse in der Frühen Neuzeit (Munich, 2007).
} 
comprehensive analysis of the most famous eyewitness accounts from the Thirty Years War. ${ }^{50}$ Both authors warn of a baroque propensity to dramatize suffering, and the fixation of baroque literature with death and the ars moriendi is well known. Nonetheless, although some accounts are clear exaggerations, relentless expressions of grief hint at the underlying fascination with fantastic images of horror in an age of curiosities. Again, Spain played a leading role; the spirit of the age was present in the theatre of the macabre and embodied in the fad for bizarre objects kept in Wunderkammer. ${ }^{51}$ Wilhelm V assembled one such Wunderkammer in his Munich residence, where it can be seen to this day. It houses a grotesque array of body parts of the saints purchased throughout the Empire. In one case, his aspirations were disappointed when his agents could not bribe locksmiths in Evangelical Nuremberg to steal local relics. Legend held that his son, Maximilian I, paid Protestants dearly to protect their unwanted relics from wanton destruction and to add prestige the image of the Bavaria Sancta - monies subsequently spent on cannon and turned on the Catholic League. ${ }^{52}$

Taken as a whole, the myth of an all-destructive war arises from the dramatic penchant of past historians to dwell on accounts of suffering. Mundane testimonies to the discipline of the armies involved, which kept potential atrocities in check, are often ignored. As Mortimer points out, the wartime memoirs of nuns reveal more balanced reporting. One example is the account of Maria Anna Junius of Bamberg. Junius was the daughter of a former mayor of Bamberg, who was accused, horribly tortured and convicted of witchcraft in 1628 by the local Catholic authorities. ${ }^{53}$ She too mentions witchcraft (rather defensively) as a possible root cause of the Kipper und Wipper inflation. However, in her later reporting on the Swedish occupation, she praises the protection her cloister received from successive Swedish commanders, who responded to her pleas for assistance on behalf of the local population on every occasion. ${ }^{54}$ Senior Swedish officers visited the convent frequently, donating money and cows to the sisters. Of course, one might suspect that Junius bore a grudge against the local administration because of its role in her father's death, and was amiably predisposed to the newcomers. However, Clara Steiger, a nun at Mariastein near Eichstätt (location of another severe witchhunt) took a similar view, noting that when the Swedes captured her convent, they expressed greater interest

50 J. Theibault, 'The Rhetoric of Death and Destruction in the Thirty Years War', Journal of Social History, 27 (1993), pp. 271-90; G. Mortimer, Eyewitness accounts of the Thirty Years War, 1618-48 (Basingstoke/New York, 2002); Mortimer, 'Style and Fictionalization in Eyewitness Personal Accounts of the Thirty Years War', German Life and Letters, 54 (2001), pp. 97-113; Mortimer, 'Individual Experience and Perception of the Thirty Years War in Eyewitness Personal Accounts', German History, 20 (2002), pp. 141-60.

51 On the baroque fascination with the bizarre, see D.R. Castillo, Baroque Horrors: Roots of the Fantastic in the Age of Curiosities (Ann Arbor, 2010). See also P. Findlen, Possessing Nature: Museums, Collecting and Scientific Culture in Early Modern Italy (Berkeley, 1996); B. Benedickt, Curiosity: A Cultural History of Early Modern Inquiry (Chicago, 2001).

52 On this and baroque necrology in general, see Lederer, Madness, Religion and the State, pp. 104-8. Rader composed his multi-volume Bavaria Sancta et Pia (a magnificently illustrated sacred geography published on oversize quarto leaves) at the behest of the Wittelsbach court between 1615 and 1628.

${ }^{53}$ As reported by H.C. Lea, Materials Toward a History of Witchcraft, vol. 3 (Philadelphia, 1890), p. 1179. Given the notoriety of both individuals, I find it remarkable that the two are generally considered in isolation. In Geoff Mortimer's recent biography, Wallenstein: The Enigma of the Thirty Years War (Basiingstoke and New York, 2010), p. 62, the author refers to the case without mentioning the individuals by name.

${ }^{54}$ Mortimer, Eyewitness Accounts, pp. $103 \mathrm{f}$. 
in food, drink and livestock than in plundering, rape or murder. The only apparent policy in action here was the enforcement of the widespread system of contributions. ${ }^{55}$ Favourable descriptions of the occupation are also found in the account of Maria Magdelena Haidenbucher, abbess of Frauenwörth.

This is hardly to say civilians were uniformly satisfied by the treatment they received at the hands of campaigning armies, both friend and foe. In order to judge their treatment soberly, Otto Ulbricht has developed a typology of confrontations between locals and occupying armies and the types of violence (to include threats of violence) suffered by civilians. ${ }^{56}$ As well as summary justice (Figure 29.20), these included pillaging (sanctioned to a certain extent by the rules of engagement), negotiations, flight and resistance.

Personal accounts regularly associate plunder with torture, whenever soldiers sought booty and became convinced that locals had hidden their valuables. A widelypublicized form of torture, the Swedish draught (Schwedischer Trunk), involved soldiers

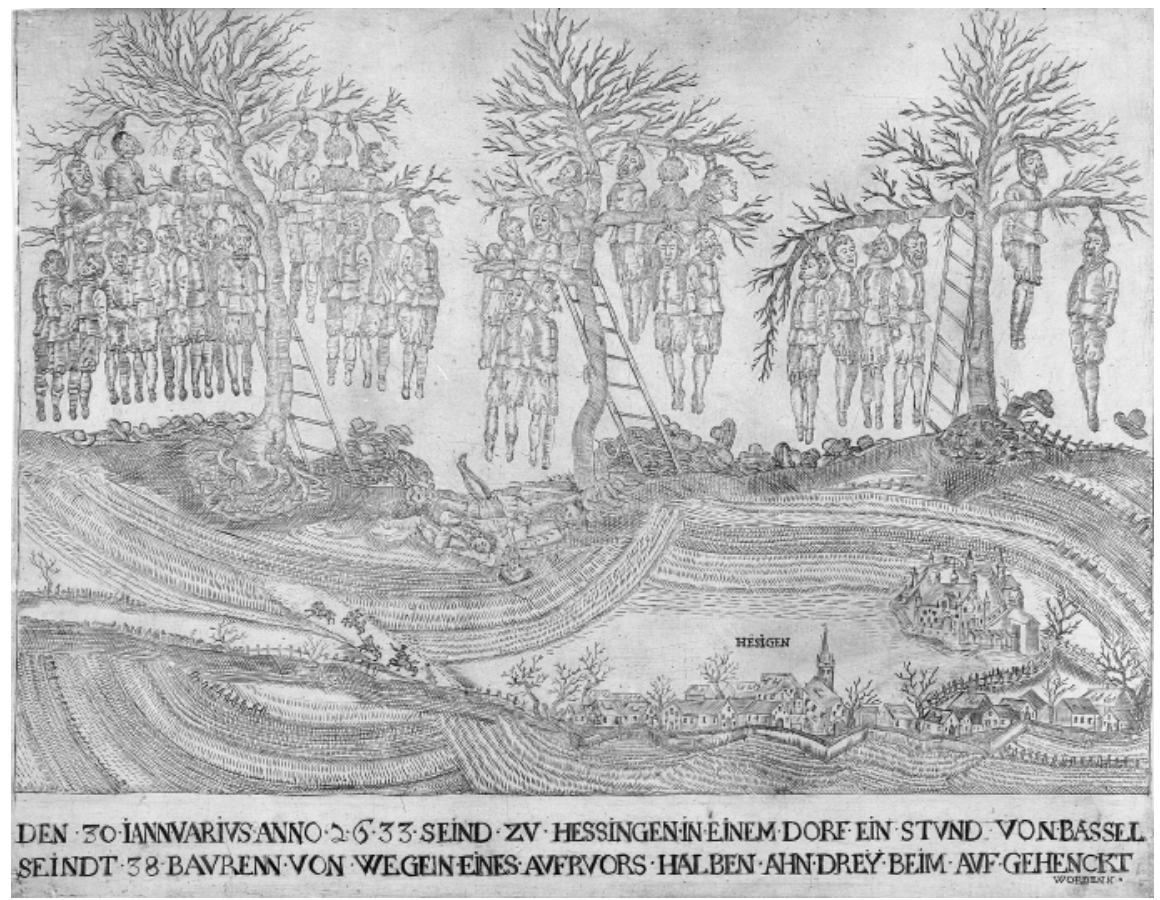

Figure 29.20: This emotive illustration of the execution of thirty-eight peasant rebels at Hessingen (near Basel) on 30 January 1633 is a bleak example of wartime suffering.

Nuremberg, Germanische National Bibliothek HB 9204/1373a.

\footnotetext{
55 See also J. Thiebault, German Villages in Crisis: Rural Life in Hesse-Kassel and the Thirty Years War, 1580-1720 (Boston, 1995), who views the war as part of a long-term crisis in early modern Germany.

${ }^{56} \mathrm{O}$. Ulbricht, 'The Experience of Violence during the Thirty Years War: A Look at the Civilian Victims', in J. Canning, H. Lehman and J. Winter, Power, Violence and Mass Death in Pre-Modern and Modern Times (Aldershot and Burlington, 2004), pp. 97-127.
} 
forcing the victim to down large quantities of agricultural slurry until revealing the location of their treasures. The claim of Martin Bötzinger to have suffered its administration twice in one day until 'my teeth were almost loosened' is regularly cited as proof that, as a group, Protestant pastors were singled out by Catholic soldiers as targets of violence, the irony of Imperial forces inflicting a Swedish draught notwithstanding. ${ }^{57}$

Such tales had a knock-on effect. The motif of peasants hiding vast hordes of wealth led to a spate of trials against treasure-hunters who actually employed supernatural means to try and locate hidden deposits guarded by the spirits of the tortured dead after the war. ${ }^{58}$ Popular legend could also become the stuff of propaganda. A fable from Rothenburg ob der Tauber recalls how war stories (in this case, the story of the Swedish draught) were translated into romanticist propaganda during the nineteenth century. Ostensibly, the sick-humoured Tilly, who had destroyed Magdeburg only months before, spared this Protestant town from destruction after a leading citizen conducted a master draught, knocking back over three litres of wine in one swallow. While the local fable (still commemorated annually in the town) might confirm torture sanctioned from above, no historical evidence exists to corroborate it. Instead, the story may simply be the product of a nineteenth-century anti-Hapsburg master-narrative which favoured a small German Protestant solution to the question of national unification, elevating Martin Luther to the status of a German founding father.

The catalogue of suffering composed by Ulbricht has an antecedent in two series of prints by the baroque draftsman from the Duchy of Lorraine, Jacques Callot. His famous cycle on suffering in wartime graphically illustrates several common forms of violence endangering public order during the war. ${ }^{59}$ However, Callot's overall statement was not intended as a condemnation of the rules of war; quite the contrary. Although he depicts scenes of disorderly plunder, burning, chaos, murder, rape and peasant uprisings, he contrasts these with the orderly mustering of troops, the distribution of compensation and legal retribution directed against offenders of order ${ }^{60}$ His most famous image, The Hanging Tree, generally evokes horrors from a modern audience-but to contemporaries, it represented justice and good public order, rather than suffering under a cruel, barbarous, chaotic regime. Callot's art moved beyond the morbid fantasies of the baroque. His illustrations served a pedagogical purpose, harbingers of Diderot's eighteenth-century Encyclopédie. As Callot was in state employ, we might think of him in the function of an embedded war-correspondent, factually recording the dangers of disorder in wartime and the advantages of disciplined hierarchical administration, rather than as an impassioned observer of the horrors of war.

57 Ulbricht, 'The Experience of Violence', p. 112; Mortimer, 'Individual Experience', pp. 150f. Others reportedly perished.

58 J. Dillinger, 'Treasure-Hunting: A Magical Motif in Law, Folklore, and Mentality, Württemberg, 1606-1770', German History, 20 (2002), pp. 161-84; D. Lederer, 'Living with the Dead: Ghosts in Early Modern Bavaria', in K.A. Edwards, Werewolves, Witches and Wandering Spirits: Traditional Belief and Folklore in Early Modern Europe (Kirksville, 2002), pp. 47-51.

59 Jacques Callot, Les misères et les malheurs de la guerre (Paris, 1633), and Callot, Les petites misères de la guerre (n.p., n.d.).

${ }^{60}$ For an interpretation of his artistic cycles on the War, see P. Choné, 'Die Kriegsdarstellungen Jacques Callots: Realität als Theorie', in Krusenstjern and Medick, Zwischen Alltag und Katastrophe, pp. 409-26. 


\section{IV: Baroque Suffering as Hyper-Cognized Expressions of Grief?}

The cost of the Thirty Years War in human terms was immense and is virtually incalculable. Like no other war in European history, historians of the period 1618 to 1648 continue to conclude their analyses on the note of pointless suffering. To that extent, study of the Thirty Years War utterly vindicates suffering as a useful category of historical analysis. General treatments invariably end in similar ideological condemnations. On the lessons learned by the participants, Wedgwood concludes with the comment, 'They did not learn then, and have not since, that war only breeds war. ${ }^{61}$ On voices from the past, Wilson reiterates (in terms hauntingly familiar to us in the twenty-first century): 'They offer a warning of the dangers of entrusting power to those who feel summoned by God to war, or feel that their sense of justice and order is the only one valid'. ${ }^{62}$ Tellingly, he brings us back to our departure point, the association of suffering with justice and injustice.

In universal terms, suffering is a biological and emotional response to pain. However, its subjective expression is informed by the poetics of a peculiar cultural context. Thus, historians of suffering are left with the dilemma of sifting biological constants from social constructs - although as William Reddy points out, perhaps we would do better to treat emotions as over-learned cognitive habits, rather than knee-jerk reactions. ${ }^{63}$ Historians generally accept the historical significance of suffering, but regularly privilege certain experiences of suffering over others. Indeed, historians are constantly confronted with the dilemma of prioritizing some events over others. The tools we use to differentiate between historically significant suffering and that which is not are often qualitative, politically, religiously or philosophically subjective and anchored in each individual's sense of justice. We weigh values against evidence and in the light of conflicting memories. In the end, establishing the historical significance of suffering is an ongoing and awkwardly Talmudic enterprise.

Still, numbers count. What do they tell us about suffering in the Thirty Years War? Some five million people perished as a result of the war, several hundred thousand during military operations, but most from the effects of famine and disease. Nonetheless, historical debate on the nature of suffering in the War still concentrates on depictions of atrocities suffered at the hands of soldiers. In fact, travelling armies destroyed crops and livestock, spreading contagious pandemics (most notably typhus, dubbed the Hungarian fever because of its presumed origins in Hungary during simultaneous campaigns against the Ottomans $\left.{ }^{64}\right)$ in their wake. The violated and dispossessed joined the armies

\footnotetext{
${ }^{61}$ Wedgewood, The Thirty Years War, p. 526.

62 Wilson, The Thirty Years War, p. 851.

${ }^{63}$ Reddy, The Navigation of Feeling, p. 34. More specifically on the Thirty Years War, the issue of biological universality in the experience of suffering and its social construction is raised poignantly in I. Ritzmann, 'Leidenserfahrung in der historischen Betrachtung: Ein Seiltanz zwischen sozialem Konstrukt und humanbiologischer Konstanz', in Münch, 'Erfahrung' als Kategorie, pp. 59-72.

${ }^{64} \mathrm{H}$. Zinnser first identified the Hungarian fever with typhus: Rats, Lice and History: A Study in Biography (New York, 1934), 268f. On its semantic uses, see A. Bähr, 'Die Semantik der Ungarischen Krankheit. Imaginationen von Gewalt als Krankheitsursache zwischen Reformation und Aufklärung', in C. Ulbrich, C. Jarzebowski and M. Hohkamp (eds), Gewalt in der Frühen Neuzeit: Beiträge zur 5. Tagung der Arbeitsgemeinschaft Frühe Neuzeit im VHD, (Historische Forschungen, 81) (Berlin 2005), pp. 359-73; On the experience of actual sufferers, see Lederer, Madness, Religion and the State, pp. $159 f$.
} 
on the clogged roads of the Empire, exacerbating the situation throughout the Empire. The historical significance of all this suffering as a determining characteristic of German history was immense and long-lasting. As a corporate body, the Holy Roman Empire in central Europe suffered its worst ever demographic crisis, at least in relative terms. One in five people died, most of them from disease, even in the absence of invading armies.

Further, despite a litany of gruesome tales of atrocities, these were seldom, if ever, the result of institutionalized practice. They occurred as individual incidents of shock and horror, multiplied by the general chaos and fear which accompanied the breakdown of the social order. According to Wedgwood, quotidian circumstances desensitized the population to suffering, at least initially, while Ergang and Thiebault point to the baroque propensity for exaggeration. However, we might just as well suggest that the climate of fear and death had over-sensitized (or hyper-cognized ${ }^{65}$ ) the population, psychologically turning their lives into a literal valley of grief (fammertal). In the most recent overview of baroque literature, the War figures as 'a trauma of German history'; as Claudia Benthen explains:

The incomprehensibility of survival in the face of war, disease, and more generally the frailty and transience of human life preoccupies baroque culture; the experience of trauma is not restricted to the individual but can also be collective. Therefore, I am not claiming that the authors mentioned in this essay necessarily experienced specific and concrete traumas in their own lives that can be inferred from their writing; however, all of them were subject to a collective traumatic disposition that becomes evident in their literary treatment of decay and transience. 'Existenzangst' (existential anxiety) is the 'Grunderfahrung der Epoche' (basic experience of the epoch) and the Thirty Years War has been frequently named a 'Trauma der deutschen Geschichte' (trauma of German history). ${ }^{66}$

If this is true, then perhaps William Reddy's model of the emotions is applicable here. Reddy argues that while hyperbolic sentimentality contributed to the French Revolution, the Terror brought about a level of political suffering which, in turn, contributed to the downfall of Robespierre and the Mountain and the end of sentimentality as a political force ${ }^{67}$ Similarly, if the Thirty Years War traumatized collective as well as individual experience through untold existential suffering, pervasive among both the indirectly and directly affected as Benthen suggests, then it can be advanced that suffering likewise contributed to the end of the War and the Peace of Münster and Osnabrück. Each new threat, each new plague only compounded the suffering. Financial ruin brought about by the Kipper und Wipper inflation (itself brought about by the unscrupulous monetary practice of debasing or even shaving coinage, in turn promoting a widespread lack of confidence in monetary instruments) reinforced apocalyptic despair. Society flailed about itself, viciously striking out at the weak, who became targets of witchcraft accusations in unprecedented numbers. If war begat war, then suffering too begat more suffering, for thirty years, in a apparently endless cycle of hopelessness. In this model (also opposed to the demographic/racial prognosis of Franz on the sustainability of the Thirty Years War), suffering emerges as a central and dynamic force in historical change.

\footnotetext{
${ }^{65}$ Reddy, The Navigation of Feeling, p. 37.

${ }^{66}$ Claudia Benthen, 'Vanitas, Vanitatum, et Omnia Vanitas: The Baroque Transience Topos and its Structural Relation to Trauma', in Lynne Tatlock (ed.), Enduring Loss in Early Modern Germany: Cross-Disciplinary Perspectives (Leiden and Boston, 2010), p. 61.

${ }^{67}$ Reddy, The Navigation of Feeling, pp. 123-129, 196f, $209 f$.
} 
It is troubling, however, when personal accounts of suffering almost unanimously refer to atrocities perpetrated by Catholics. These still come to the fore in most historical accounts. Tilly has become a frequent bogey-man. Protestant pastors complained regularly of mistreatment, while Catholic nuns expressed gratitude to the Swedish invaders. Here, it seems odd that prominent historians should cite the same cases (such as Pastor Bötzinger receiving the Swedish draught from Imperial troops) over and over again. Certainly, Catholic accounts such as the diary of the monk Maurus Freisenegger also testify to a litany of atrocities, but they still receive far less attention. In the face of such historiographic reiteration, one begins to wonder if Friedrich Schiller and Gustav Freytag weren't right after all. In this regard, apparently, memory and memorialization of the Thirty Years War remains selective. ${ }^{68}$

Numerically, there are reasons for this, of course. The Evangelical movement was premised upon the doctrine of scripture alone, encouraging the common man to literacy. Evangelicals were prolific producers of texts in the sixteenth and seventeenth centuries, while many ordinary Catholics continued to exist in a culture of orality. As we have seen, unofficial Catholic literary depictions of wartime suffering were generally composed by members of the clergy, nuns and monks. Where ordinary Catholics did excel was in the representation of their suffering in folk art, particularly the production of countless votive paintings, still available from all parts of the Empire. As in broadsheets, brief captions explain events depicted in the paintings. In Bichl, for example, a marvellous votive painting representing the terrible plague during the Swedish invasion of 1634 still adorns the local church on a hilltop in silent testimony to death and suffering among humans and livestock alike. Clearly, there remains room for the incorporation of such non-literary sources into the current catalogue of Selbstzeugnisse and ego-documents on suffering, presenting us with at least one interesting challenge for future research. ${ }^{69}$ However, caution is the watchword here, for, as the anthropologists Arthur and Joan Kleinman point out, images of suffering incorporate powerfully emotive elements and can easily be essentialized, naturalized or even sentimentalized to the point of commodification. ${ }^{70}$ Certainly, there is no lack of available visual evidence for interpretations of suffering in the Thirty Years War, especially in the arena of woodcuts and broadsheets, with voluminous edited collections readily available. ${ }^{71}$ The most recent, comprehensive collection of sources from the war by Peter Wilson rectifies this problem only to the extent of including visual evidence from the famous Callot series, while its documentary evidence on 'Experience' retains old favourites such as Pastors Bötzinger and Ludolph and Sister Junius. ${ }^{72}$

\footnotetext{
${ }^{68}$ On the memorialization of the war, see H. Medick, 'The Thirty Years War as Experience and Memory: Contemporary Perceptions of a Macro-Historical Event', in Tatlock, Enduring Loss, pp. 25-50.

${ }^{69}$ And here, I agree completely with Greyerz on the continuing vitality of the concept of ego-documents: 'Ego-Documents: The Last Word?', German History, 28 (2010), pp. 273-82.

${ }^{70}$ Arthur \& Joan Kleinman, "The Appeal of Experience; The Dismay of Images: Cultural Appropriations of Suffering in Our Times," in Kleinman, Das \& Lock, Social Suffering, pp. 1-23.

${ }^{71}$ Three important multi-volume collections include: John Roger Paas, The German Political Broadsheet; Dorothy Alexander and Walter Strauss, The German Single-Leaf Woodcut 1600-1700 (New York, 1977); Wolfgang Harms, Deutsche Illustrierte Flugblätter des 16. und 17. Jahrhunderts (Tübingen, 2005).

72 P.H. Wilson, The Thirty Years War: A Sourcebook (Basingstoke and New York, 2010).
} 
In the end, what does the Thirty Years War teach us about suffering in wartime and how does this contribute to the larger narrative of German history? As the prime example of a war characterized primarily by suffering, it teaches us, above all, to be cautious and sober in our evaluation of wartime suffering. We quickly learn that in the midst of so many conflicting claims of suffering, we need to identify and establish specific criteria for its measurement, which are neither biologically wooden nor constructivist to the point of absolute relativity - a politically charged endeavour, to say the least, but perhaps the work of William Reddy on the French Revolution, or even the Universal Declaration of Human Rights offer useful guidance. We also learn that what we view as over-dramatization may in fact be an indicator of a society that was hyperbolically sensitive to violence and suffering, rather than inured as Wedgewood suggests. Further, while Franz's empirical evidence on the role of disease has proved correct, his theoretical framework, based primarily on Nazi ideology, has not surprisingly proved woefully pseudo-scientific. Overall, the historiography of the Thirty Years War vindicates the role of suffering in history and its significance as a useful theoretical and methodological tool for all historians, cultural, political, military and otherwise. Finally, in response to the absurd rhetorical question posed initially, 'do Germans suffer?', the answer - at least for the Thirty Years War — has to be overwhelmingly: yes, millions of them did.

\begin{abstract}
Like perhaps no other military struggle in German history, the Thirty Years War exemplifies a conflagration largely defined by immense suffering. It offers an optimal testcase for the analysis of suffering as an emotional category by historians. In the twentieth century, some (such as Dame C.V. Wedgewood or the SS officer Günther Franz) employed a political frame of reference to more recent events in German history. One of the inadequacies of this interpretative framework is its tendency to moralize and over-simplify the roles of victims and perpetrators. In fact, we now recognize that most suffering during the Thirty Years War related only indirectly to military conflict, resulting instead from economic disaster, famine and disease. As a direct outcome of the war, rape poignantly illustrates methodological difficulties facing historians of suffering, given the patriarchal character of seventeenth-century society. The present historiography overcomes a variety of obstacles through micro-historic methods employing so-called ego-documents and Selbstzeugnisse. Theoretically, William Reddy's exploration of hyperbolic sentimentality during the French Revolution may offer us a better analytical framework for understanding suffering during the Thirty Years War. In our case, a hyperbolic sensitivity to suffering shared by victims and non-victims alike contributed to the cessation of hostilities at Münster/Osnabrück and enshrined principles of sovereignty and religious tolerance in the Western political vocabulary. Thus elevated, the mechanisms of emotional suffering assume a central explanatory role in our understanding of the Thirty Years War.
\end{abstract}

Keywords: destruction of Magdeburg, Günther Franz, Dame C. V. Wedgewood, emotions (history of), ego-documents; rape 